\title{
Deteksi Level Kolesterol melalui Citra Mata Berbasis HOG dan ANN
}

\section{MUHAMMAD ARSYAD SIDDIK, LEDYA NOVAMIZANTI, I NYOMAN APRAZ RAMATRYANA}

\author{
Program Studi S1 Teknik Telekomunikasi, Fakultas Teknik Elektro, \\ Telkom University \\ Email: muhammadarsyadsiddik@students.telkomuniversity.ac.id
}

Received 30 Desember 2018 | Revised 21 Januari 2019 | Accepted 24 Maret 2019

\begin{abstract}
ABSTRAK
Kolesterol merupakan lemak yang berada di dalam darah yang dibutuhkan untuk pembentukan hormon dan sel baru. Kadar kolesterol normal harus kurang dari 200 mg/dL, namun jika di atas 240 mg/dL akan berisiko tinggi terkena penyakit stroke dan jantung koroner. Penelitian ini menghasilkan suatu sistem yang dapat mendeteksi kadar kolesterol seseorang melalui citra mata menggunakan metode iridologi dan image processing. Citra mata diperoleh dari pasien laboratorium klinik sebanyak 120 citra mata. Proses sistem diawali dengan mengolah citra mata dengan metode cropping, resize, dan segmentasi. Metode ekstaksi ciri menggunakan Histogram of Oriented Gradients (HOG), dan klasifikasi menggunakan Artificial Neural Network (ANN). Sistem dapat mendeteksi kadar kolesterol dengan tiga level klasifikasi, yaitu normal, berisiko kolesterol tinggi, dan kolesterol tinggi dengan tingkat akurasi sebesar 93\% dan waktu komputasi 0,0862 detik.
\end{abstract}

Kata kunci: citra mata, kadar kolesterol, Histogram of Oriented Gradients, Artificial Neural Network

\begin{abstract}
Cholesterol is fat in the blood that is needed for the formation of hormones and new cells. Normal cholesterol levels should be less than $200 \mathrm{mg} / \mathrm{dL}$, but if above $240 \mathrm{mg} / \mathrm{dL}$ will be at high risk of stroke and coronary heart disease. This study produced a system that can detect a person's cholesterol levels through eye images using iridology and image processing methods. Eye images obtained from clinical laboratory patients were 120 eye images. The system process begins with processing eye images using the method of cropping, resizing, and segmentation. Feature extraction method uses Histogram of Oriented Gradients (HOG), and classification using Artificial Neural Network (ANN). The system can detect cholesterol levels with three levels of classification, namely normal, at high risk of cholesterol, and high cholesterol with an accuracy rate of $93 \%$ and computing time of 0.0862 seconds.
\end{abstract}

Keywords: eye image, cholesterol level, Histogram of Oriented Gradients, Artificial Neural Network 


\section{PENDAHULUAN}

Kolestrol adalah suatu lemak yang terdapat di dalam aliran darah yang diperlukan untuk pembentukan dinding sel. Jika kadar kolestrol yang berada di dalam darah berlebih, akan menyebabkan penyakit yang berbahaya seperti penyakit stroke dan jantung koroner (Adi et al, 2015), (Adi \& Rao, 2017). Deteksi kadar kolesterol berperan penting dalam pencegahan penyakit stroke dan jantung koroner (Kumar et al, 2016). Pada umumnya, pemeriksaan kadar kolesterol melalui pemeriksaan darah di laboratorium rumah sakit. Waktu yang dibutuhkan untuk mendapatkan hasil kadar kolesterol di laboratorium sekitar dua jam, karena standar operasional dari sistem pemeriksaan. Oleh karena itu, dibutuhkan suatu metode teknologi yang praktis untuk memenuhi kebutuhan masyarakat di bidang kesehatan. Metode yang digunakan untuk mendeteksi kadar kolesterol yaitu metode pemeriksaan melalui iris mata yang disebut dengan iridologi (Ramlee et al, 2016). Iridologi merupakan metode untuk mengetahui kondisi sejumlah organ dan sistem dalam tubuh melalui ciri-ciri yang ada pada iris mata. Sebelumnya telah banyak ahli iridologi yang telah mempelajari pola-pola pada iris mata, dan menghubungkannya dengan masalah kesehatan tertentu (Kumar et al, 2016), (Ramlee et al, 2016). Melalui pengamatan dan observasi, mereka mendapati adanya polapola yang beraturan yang mengindikasikan adanya kelemahan fisik dalam diri seseorang, karena orang-orang yang memiliki pola iris mata sama ternyata mengalami masalah kesehatan yang sama.

Pada tahun 2014, telah dilakukan penelitian untuk mendeteksi ada atau tidak adanya kolesterol tinggi pada seseorang melalui gambar hasil Magnetic Resonance Imaging (MRI) menggunakan metode Discrete Wavelet Transform (DWT) dan ANN, dimana akurasi untuk kolesterol normal $89,6 \%$, dan akurasi untuk kolesterol tinggi 97,6 \%. Pada penelitian tersebut, klasifikasi dengan metode ANN dapat meminimalkan tingkat kesalahan antara nilai keluaran pada jaringan dengan nilai keluaran yang diinginkan (Adi et al, 2015). Pada tahun 2017, penelitian tersebut diperbaiki dengan penambahan metode Singular Value Decomposition (SVD) dan hasilnya menjadi lebih baik dari sebelumnya (Adi \& Rao, 2017). Pada tahun 2016, telah dilakukan penelitian non-invasive kadar kolesterol melalui citra mata menggunakan metode Gray Level Mean (GLM) dan regresi linier, dengan nilai akurasi 97,06\% (Kumar et al, 2016). Pada tahun yang sama, telah dilakukan penelitian deteksi kolesterol melalui corneal arcus menggunakan metode Gray Level Co-occurrence Matrix (GLCM) dan Bayesian Regulation Backpropagation Neural Network (BRBNN), didapatkan sensitivitas 94,1\%, spesifisitas 97,3\% dan akurasi 96\% (Ramlee et al, 2016). Kemudian, pada tahun yang sama telah dilakukan penelitian dengan masukan data sesuai informasi rekam medik pasien untuk memprediksi dan mendeteksi kardiovaskular lipid darah dengan menggunakan metode jaringan syaraf tiruan dan algoritma Particle Swarm Optimization (PSO) dengan akurasi sebesar 93,22\% (Baghini et al, 2017). Keseluruhan penelitian tersebut, hanya mendeteksi kadar kolesterol menjadi 2 klasifikasi, yaitu kolesterol normal dan kolesterol tinggi.

Histogram Of Oriented Gradients merupakan deskriptor yang mewakili suatu objek. Pada tahun 2017, telah dilakukan penelitian deteksi osteoarthritis lutut melalui gambar sinar-X menggunakan metode HOG dan SVM, dengan tingkat akurasi 95\%. Metode HOG merupakan deskripsi fitur yang baik dalam analisis gambar dan pengenalan objek (Gornale et al, 2017). Pada tahun yang sama, telah dilakukan penelitian untuk mendesain sebuah kontrol kecepatan motor induksi. Motor yang menggunakan kontrol backpropagation neural network memiliki kinerja yang lebih baik daripada motor tanpa kontrol, dikarenakan kecepatan dapat diatur sesuai kebutuhan dunia industri (Djalal et al, 2017). 
Berdasarkan penelitian yang telah dilakukan sebelumnya, peneliti membuat suatu sistem yang dapat mendeteksi kadar kolesterol seseorang melalui citra mata menggunakan metode iridologi, ekstraksi ciri HOG, dan klasifikasi ANN. Sistem diharapkan dapat mendeteksi kadar kolesterol dengan tiga level klasifikasi, yaitu kolesterol normal, berisiko kolesterol tinggi, dan kolesterol tinggi. Rumusan masalah yang dibahas pada sistem ini antara lain: merancang sistem deteksi kadar kolesterol menggunakan metode HOG dan ANN, menentukan parameter dari metode yang memberikan tingkat akurasi terbaik, dan menganalisis performansi sistem berdasarkan tingkat akurasi dan waktu komputasi.

\subsection{Kolesterol}

Kolestrol dikatakan normal jika nilai kadar di bawah $200 \mathrm{mg} / \mathrm{dL}$, jika kadar kolesterol diatas $240 \mathrm{mg} / \mathrm{dL}$ maka berisiko tinggi terkena penyakit stroke dan jantung koroner. Kadar kolestrol tinggi umumnya diderita oleh orang yang menderita obesitas, namun orang yang tidak menderita obesitas juga bisa mengalaminya, apalagi dengan mengonsumsi makanan yang berlemak tinggi. Selain dari makanan, kolesterol juga diproduksi oleh tubuh kita sendiri melalui hasil konversi kalori yang tidak terpakai, kemudian disimpan untuk cadangan energi bagi tubuh.

\subsection{Indikator Kolesterol pada Iris Mata}

Pada iris mata manusia terdapat ribuan saraf yang terhubung ke seluruh tubuh. Kolesterol merupakan lemak yang terdapat pada aliran darah dapat diamati melalui iris mata, yaitu ditandai dengan adanya cincin putih yang terdapat pada iris mata. Semakin tebal cincin putih tersebut menunjukan semakin besar kadar kolestrol yang dimiliki seseorang (Kumar et al, 2016),(Songire \& Joshi, 2016).

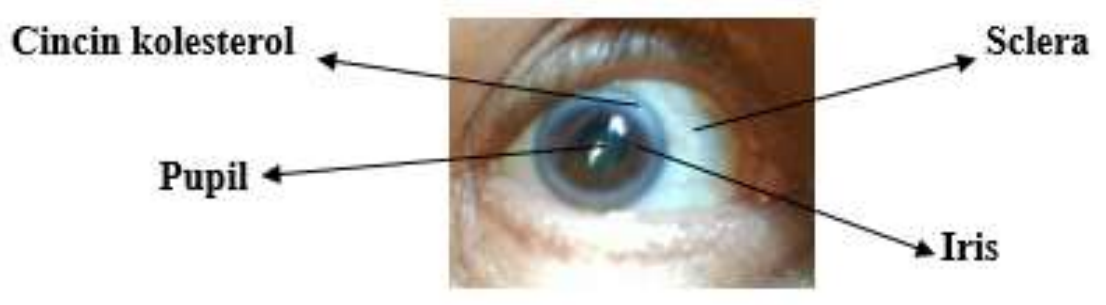

Gambar 1. Bagian-bagian Mata

\subsection{Citra Digital}

Citra digital dinyatakan sebagai fungsi dari dua dimensi yaitu $f(x, y)$, dimana $x$ dan $y$ merupakan posisi koordinat, dan $f$ merupakan intensitasnya. Sebuah citra digital dapat dinyatakan dengan

$$
A=\left(\begin{array}{ccc}
f(1,1) & \cdots & f(1, n) \\
\vdots & \ddots & \vdots \\
f(m, 1) & \cdots & f(m, n)
\end{array}\right)
$$

Tipe citra yang digunakan dalam penelitian ini, yaitu (Munir, 2004):

1. Citra warna

Citra warna merupakan citra yang tiap pikselnya mempunyai tiga komponen warna yang spesifik, yaitu merah (red), hijau (green), dan biru (blue). Penentuan warna setiap piksel bergantung pada kombinasi dari intensitas merah, hijau dan biru. Pada format file grafis, komponen merah, hijau dan biru masing-masing bernilai 8 bit. Sehingga citra warna disebut sebagai citra intensitas 24 bit. 
2. Citra Grayscale

Citra grayscale merupakan citra berskala keabuan yang menangani gradasi warna hitam dan putih. Warna citra grayscale dinyatakan dengan intensitas berkisar antara 0 sampai dengan 255 . Nilai 0 menyatakan warna hitam dan nilai 1 menyatakan warna putih. Rumus untuk mengubah citra warna ke citra grayscale ditunjukkan pada Persamaan (2).

$$
I=0,2989 \times R+0,5870 \times G+0,1141 \times B
$$

Dimana $R$ adalah nilai piksel untuk warna merah, $G$ adalah nilai piksel untuk warna hijau dan $B$ adalah nilai piksel untuk warna biru.

3. Citra Biner

Citra biner adalah citra digital yang hanya memiliki dua kemungkinan nilai piksel yaitu 0 (hitam) dan 1 (putih). Karena jumlah warna pada citra biner adalah 2, maka setiap piksel hanya memiliki ukuran 1 bit. Rumus untuk mengubah citra grayscale ke citra biner ditunjukkan pada Persamaan (3).

$$
g(x, y)=\left\{\begin{array}{l}
1, f(x, y) \geq T \\
0, f(x, y)<T
\end{array}\right.
$$

Dimana $g(x, y)$ adalah citra biner, $f(x, y)$ adalah nilai piksel pada citra grayscale, dan $\mathrm{T}$ adalah nilai ambang.

\subsection{Histogram}

Histogram dari suatu citra merupakan grafik yang menggambarkan penyebaran nilai-nilai intensitas piksel dari bagian tertentu di dalam citra. Sebuah histogram dapat menunjukkan banyak informasi, diantaranya kecerahan (brightness) dan kontras (contrast) dari suatu gambar. Misal citra digital memiliki $L$ derajat keabuan, yaitu dari 0 sampai $L-1$. Rumus dari histogram citra ditunujukkan pada Persamaan (4) (Novamizanti, 2009).

$$
h_{i}=\frac{n_{i}}{n}, \quad i=0,1, \ldots, L-1
$$

dimana $n_{i}$ merupakan jumlah piksel yang memiliki derajat keabuan $i$, dan $n$ merupakan jumlah seluruh piksel di dalam citra.

Misal diberikan matriks

$$
A=\left[\begin{array}{ccccccccc}
0 & 0 & 250 & 250 & 250 & 250 & 0 & 0 & 0 \\
0 & 210 & 250 & 0 & 0 & 250 & 210 & 0 & 0 \\
0 & 210 & 250 & 0 & 0 & 250 & 210 & 0 & 0 \\
0 & 0 & 210 & 250 & 250 & 210 & 0 & 0 & 0
\end{array}\right]
$$

yang menyatakan citra digital berukuran $4 \times 9$ piksel, dengan derajat keabuan dari 0 sampai 255. Sehingga diperoleh nilai $n=36$. Hasil perhitungan histogram-nya dapat dilihat pada Tabel 1. Dengan demikian, nilai $n_{i}$ berbanding lurus dengan nilai $h_{i}$.

Tabel 1. Hasil Perhitungan Histogram

\begin{tabular}{|c|c|c|}
\hline Intensitas Piksel & $\boldsymbol{n}_{\boldsymbol{i}}$ & $\boldsymbol{h}_{\boldsymbol{i}}=\boldsymbol{n}_{\boldsymbol{i}} / \boldsymbol{n}$ \\
\hline 0 & 20 & 0,55 \\
\hline 210 & 6 & 0,16 \\
\hline 250 & 10 & 0,27 \\
\hline
\end{tabular}




\subsection{Histogram of Oriented Gradients}

Histogram of Oriented Gradients(HOG) merupakan deskriptor yang mewakili suatu objek. Cara kerja dari HOG yaitu dengan menghitung nilai gradien dari suatu daerah tertentu pada citra. Pada setiap citra memiliki karakteristik yang ditunjukkan oleh suatu nilai gradien yang didapatkan dengan membagi suatu citra ke dalam daerah terkecil yang disebut sel. Tahapan dari metode HOG adalah sebagai berikut (Nazir, Jan, \& Sajjad, 2017):

a. Tentukan cell size dan block size. Misal diketahui cell size dengan ukuran $4 \times 4$ piksel. Maka block size $2 \times 2$ cell diilustrasikan seperti pada Gambar 2 .

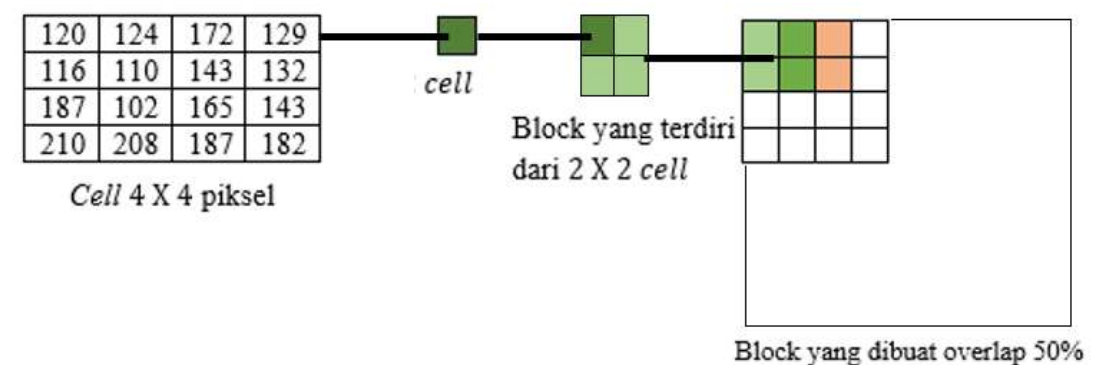

\section{Gambar 2. Ilustrasi Cell Size dan Block Size}

b. Hitung nilai gradien $(|\mathrm{G}|)$ dan orientasi gradien $(\theta)$, menggunakan Persamaan (5) dan (6).

$$
\begin{gathered}
|\mathrm{G}|=\sqrt{k_{x}{ }^{2}+k_{y}{ }^{2}} \\
\theta=\tan ^{-1} \frac{k_{x}}{k_{y}}
\end{gathered}
$$

Dimana $k$ merupakan citra skala keabuan, $k_{x}$ merupakan matriks terhadap sumbu-x dan $k_{y}$ adalah mariks terhadap sumbu-y.

$$
k_{x}=k * f_{x} ; k_{y}=k * f_{y}
$$

Dengan $f_{x}$ adalah kernel $\left[\begin{array}{lll}-1 & 0 & 1\end{array}\right], f_{y}$ adalah kernel $\left[\begin{array}{c}-1 \\ 0 \\ 1\end{array}\right]$. Variabel $k_{x}$ dan $k_{y}$ dihitung menggunakan konvolusi.

c. Hitung bin orientasi dari orientasi gradien setiap sel. Setiap piksel dalam satu sel mempunyai nilai histogram berdasarkan perhitungan nilai gradien. Bin orientasi terdiri dari 9 elemen array yang direpresentasikan dengan selisih sudut $20^{\circ}$, misal $0^{\circ}, 20^{\circ}, 40^{\circ}, 60^{\circ}$ dan sebagainya.

d. Lakukan normalisasi pada setiap blok, dengan cara membagi masing-masing elemen vektor dengan panjang vektor sehingga menghasilkan vektor satuan. Tujuan dari normalisasi blok untuk mengurangi efek perubahan kecerahan objek pada satu blok.

e. Gabungkan seluruh histogram dari setiap cell dengan semua blok yang telah dinormalisasi membentuk sebuah vektor ciri HOG (Gornale et al, 2017). 


\subsection{Artificial Neural Network (ANN)}

Artificial Neural Network (ANN) merupakan sistem komputasi dimana arsitektur dan operasi didapat dari pengetahuan sel saraf pada otak manusia. ANN dapat digambarkan sebagai model matematis dan komputasi untuk fungsi klasifikasi data. ANN dirancang dan dilatih untuk memiliki kemampuan mengingat suatu informasi pola secara menyeluruh dan mengadaptasi pemrosesan pola dengan baik, dapat digunakan untuk proses belajar dan menghasilkan operasi dari beberapa contoh untuk menghasilkan output yang sempurna, dari input yang dimasukkan dan membuat prediksi kemungkinan outputyang akan muncul (Adi et al, 2015).

\section{METODOLOGI PENELITIAN}

Penelitian ini bertujuan untuk merancang sebuah sistem deteksi kolesterol melalui citra mata dengan kondisi normal, berisiko kolesterol tinggi dan kolesterol tinggi menggunakan metode Histogram of Oriented Gradients sebagai ekstraksi ciri dan Artificial Neural Network sebagai klasifikasi.

Tahapan metodologi yang digunakan dalam penelitian ini sebagai berikut:

1. Melakukan studi pustaka perihal :

a. Kolesterol dan indikatornya pada iris mata,

b. Pengolahan citra digital,

c. Algoritma Histogram of Oriented Gradients,

d. Algoritma Artificial Neural Network.

2. Pengumpulan data

Data citra mata diperoleh dari Rumah Sakit Al-Islam dan TelkoMedika. Penelitian ini menggunakan citra mata sebanyak 120, diantaranya 60 citra latih dan 60 citra uji. Untuk setiap citra latih maupun citra uji, masing-masing terdiri dari 20 citra mata berkolesterol normal, 20 citra mata berisiko kolesterol tinggi dan 20 citra mata berkolesterol tinggi.

3. Desain sistem

Dalam perancangan dan implementasinya, sistem ini menjelaskan gambaran umum yang dibagi menjadi 4 tahap utama, yaitu akuisisi data atau pengambilan citra mata, preprocessing untuk mendapatkan citra terbaik, ekstraksi ciri untuk memunculkan ciri-ciri khusus yang terdapat pada citra tersebut serta klasifikasi citra menggunakan data uji. Perancangan sistem ini dibuat untuk mendeteksi level kadar kolesterol menggunakan indikator citra mata, citra mata diambil menggunakan kamera dengan resolusi minimal 8 Mega piksel. Keempat tahap tersebut ditunjukkan dalam bentuk diagram blok seperti Gambar 3.

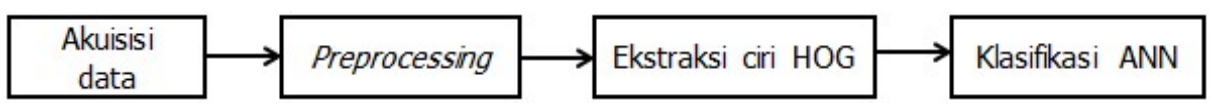

\section{Gambar 3. Diagram Blok Sistem Deteksi Kolesterol}

Sistem dirancang dan diimplementasikan menggunakan software MATLAB 2017b. Tahap awal sistem adalah akuisisi data atau pengambilan citra mata menggunakan kamera. Data citra mata yang diperoleh, selanjutnya masuk ke proses preprocessing untuk menghilangkan noise yang tidak diperlukan pada tahap berikutnya, keluaran dari preprocessing berupa citra grayscale. Selanjutnya citra tersebut diproses menggunakan metode ekstraksi ciri HOG, dan diklasifikasi dengan metode ANN dalam tiga kelas, yaitu kolesterol normal, berisiko kolesterol tinggi, dan kolesterol tinggi. Klasifikasi melalui dua 
tahap, yaitu tahap latih sebagai pencarian nilai parameter terbaik yang akan menjadi acuan sebagai database program untuk klasifikasi ANN, tahap uji sebagai proses yang digunakan dalam tahap pengujian data sehingga data dapat diklasifikasikan.

\subsection{Akuisisi Data}

Akuisisi data merupakan tahapan awal pengambilan citra mata dengan bantuan kamera. Selanjutnya software MATLAB akan memproses data hasil dari kamera. Proses akuisisi data menghasilkan foto mata dengan format .bmp atau data citra mata yang akan diproses ke tahap preprocessing.

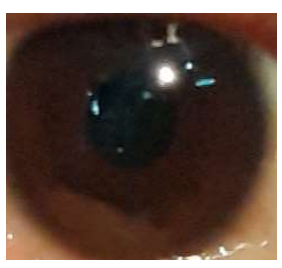

(a)

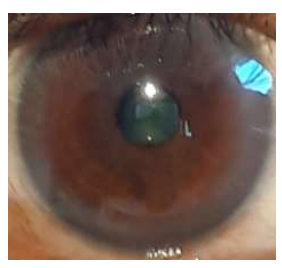

(b)

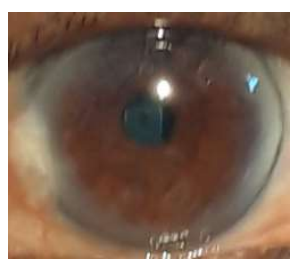

(c)

Gambar 4. Citra Mata (a) Normal (116 mg/dL), (b) Berisiko Kolesterol (207 mg/dL), (c)

Kolesterol Tinggi (259 mg/dL)

\subsection{Preprocessing}

Preprocessing merupakan tahap lanjutan setelah data citra mata diperoleh. Proses preprocessing ditunjukkan dalam Gambar 5.

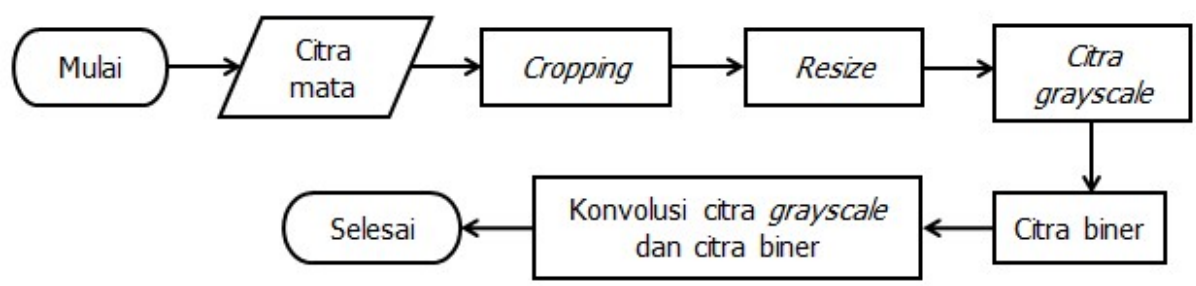

\section{Gambar 5. Diagram Alir Preprocessing}

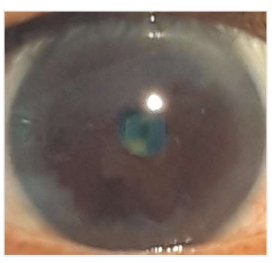

(a)

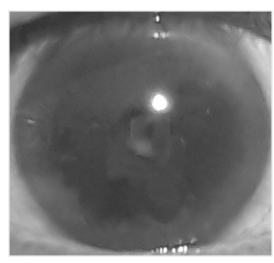

(b)

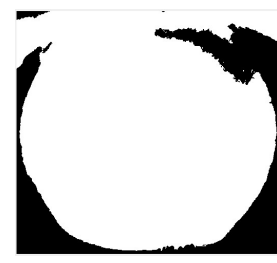

(c)

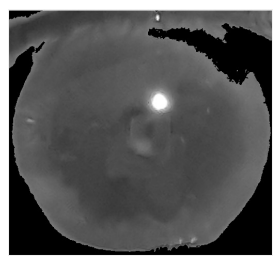

(d)

Gambar 6. Hasil Preprocessing, (a) Citra Mata Hasil Cropping, (b) Citra Grayscale, (c) Citra Biner, (d) Hasil Konvolusi Citra Grayscale dan Citra Biner

Ada beberapa tahap dalam melakukan proses preprocessing, yang pertama: citra mata dilakukan cropping, artinya memfokuskan lokasi yang diinginkan pada citra. Pada penelitian ini, cropping dilakukan untuk mendapatkan citra mata tanpa kelopak mata. Setelah itu dilakukan resize, yang bertujuan untuk menyamakan ukuran file citra menjadi $600 \times 600$ piksel. Selanjutnya citra tersebut dikonversi ke citra grayscale, yang bertujuan untuk mengubah citra warna menjadi citra grayscale, dimana hasil dari proses ini adalah tingkat keabuan 8 bit. Kemudian citra grayscale tersebut dikonversi lagi ke citra biner, untuk 
segmentasi citra grayscale. Sehingga citra yang diproses ke tahap ekstraksi ciri hanya bola mata saja. Tahap terakhir adalah konvolusi dari citra grayscale dan citra biner yang merupakan citra hasil preprocessing (Novamizanti, 2009).

\subsection{Ekstraksi Ciri}

Citra hasil preprocessing kemudian diproses ke tahap selanjutnya yaitu proses ekstraksi ciri menggunakan metode HOG. Tahap ekstraksi ciri ditunjukkan pada Gambar 7.

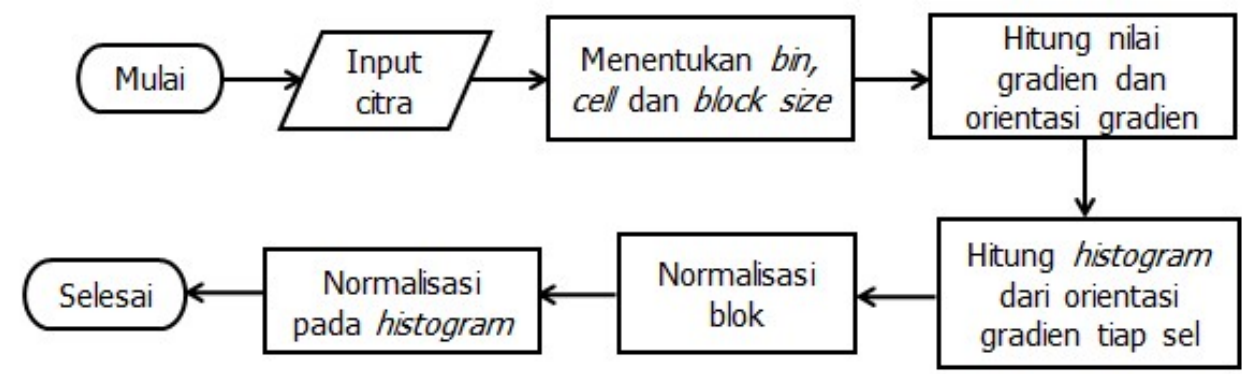

Gambar 7. Diagram Alir Ekstraksi Ciri

Tahapan dalam ekstraksi ciri menggunakan HOG antara lain:

1. Tentukan cell size, block size dan bin histogram, misalkan ukuran sel $8 \times 8$ piksel, ukuran blok $2 \times 2$ sel atau $16 \times 16$ piksel dan bin histogram 9 elemen array.

2. Hitung nilai gradien citra dengan menggunakan Persamaan (5).

3. Hitung histogram dari orientasi gradien tiap sel dengan menggunakan Persamaan (6) dan memasukkan nilai gradiennya.

4. Lakukan normalisasi blok, agar fitur citra tidak berubah terhadap kecerahan yang bervariasi dengan cara membagi setiap elemen vektor dengan panjang vektornya. Contoh sebuah vektor [125 25 65] dan panjang vektornya adalah $\sqrt{125^{2}+25^{2}+65^{2}}=$ 143,091. Dengan membagi masing-masing elemen vektor dengan panjang vektornya akan menghasilkan vektor ternormalisasi, yaitu $[0,8740,1750,454]$. Sekarang jika ada sebuah vektor $\frac{1}{2}$ kalinya $[62,512,532,5]$ ketika vektor tersebut dinormalisasi akan menghasilkan vektor yang sama yaitu $[0,874$ 0,175 0,454].

5. Lakukan normalisasi pada histogram. Pada tahap ini dilakukan normalisasi vektor histogram yang sudah dibuat pada blok $2 \times 2$ sel. Masing-masing sel memiliki histogram sebesar $1 \times 9$ elemen, sehingga pada 1 blok terdapat vektor sebesar $1 \times$ 36 elemen. Proses normalisasi histogram sama dengan proses normalisasi blok. Untuk menghitung vektor HOG, maka vektor $1 \times 36$ elemen kemudian digabungkan dengan blok-blok yang lain.

\subsection{Klasifikasi}

Tahap klasifikasi menggunakan algoritma Artificial Neural Network untuk mengelompokkan citra mata. Klasifikasi dibangun menjadi dua proses, yaitu proses latih dan proses uji. Proses latih merupakan pembentukan database yang menyimpan target terbaik dari data citra mata normal, beresiko dan kolesterol tinggi untuk klasifikasi artificial neural network. Klasifikasi didasarkan pada vektor ciri yang diperoleh dari tahap ekstraksi ciri. Vektor ciri ini kemudian akan melakukan pengecekan ke database latih untuk kemudian dilakukan pengelompokan. 
Gambar 8 merupakan diagram alir untuk proses klasifikasi.

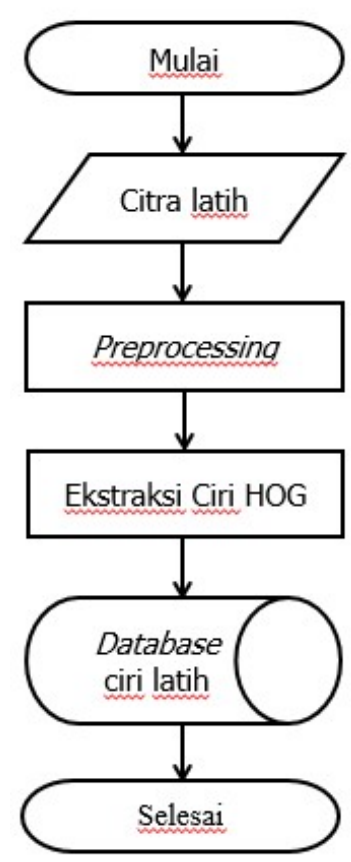

(a)

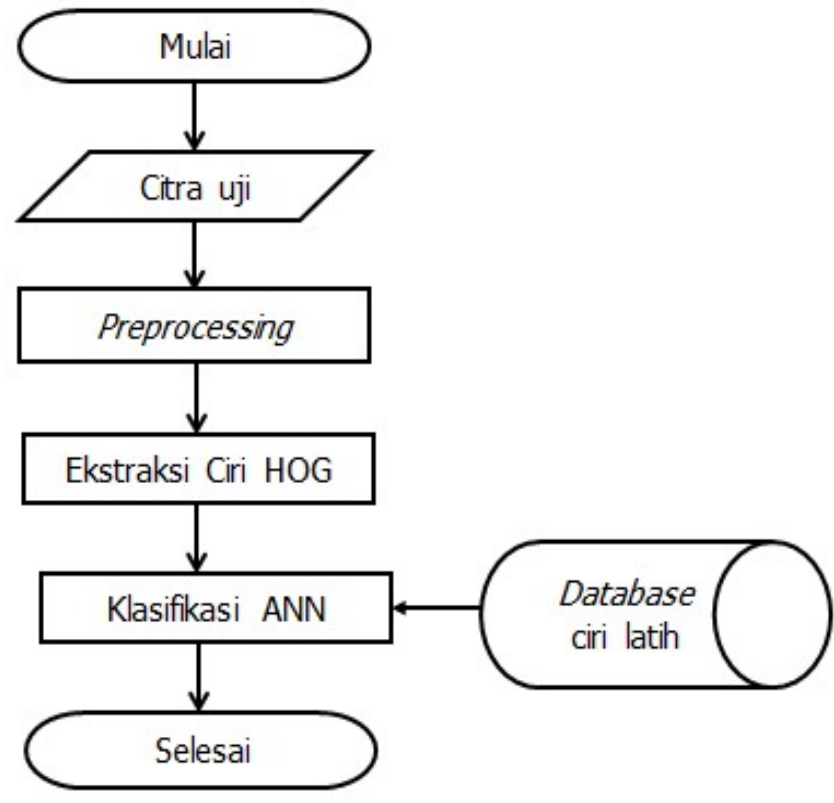

(b)

\section{Gambar 8. Diagram Alir Klasifikasi (a) Proses Latih, (b) Proses Uji}

Pada Gambar 8(a), citra latih melalui tahap preprocessing. Kemudian, citra hasil preprocessing dimasukkan ke dalam proses ektraksi ciri menggunakan HOG, sehingga menghasilkan nilai ciri latih. Kumpulan dari ciri latih dimasukkan ke dalam database ciri latih. Pada Gambar 8(b), proses diawal sama dengan Gambar 8(a). Namun, pada proses ekstraksi ciri menghasilkan ciri uji. Selanjutnya, tentukan nilai parameter hidden layer dan lakukan proses pelatihan dengan menggunakan ANN. Hasil dari ANN berupa database training ciri latih. Kemudian, proses klasifikasi dengan JST dengan cara membandingkan nilai ciri uji dengan nilai ciri yang ada pada database. Hasil dari tahap klasifikasi pada proses uji berupa level kolesterol sesuai kelas hasil pengelompokan, yaitu kolesterol normal, berisiko kolesterol tinggi, dan kolesterol tinggi.

\section{HASIL DAN PEMBAHASAN}

Untuk mendapatkan parameter terbaik dari sistem yang telah dirancang, maka dilakukan skema pengujian pada data latih. Jumlah data latih yang digunakan sebanyak 60 citra mata yang terdiri dari 20 citra mata berkolesterol normal, 20 citra mata berisiko kolesterol tinggi dan 20 citra mata berkolesterol tinggi. Beberapa parameter yang diujikan pada proses pengujian, antara lain: cell size $(2 \times 2$ piksel, $6 \times 6$ piksel dan $8 \times 8$ piksel $)$, block size $(2 \times 2$ cell, $8 \times 8$ cell dan $12 \times 12$ cell), bin number $(9,12$ dan 18), dan hidden layer (10, 50 dan 100).

Performansi sistem diukur berdasarkan tingkat akurasi dan waktu komputasi. Akurasi sistem merupakan ketepatan sistem dalam mengenali masukan yang diberikan, sehingga sistem dapat menghasilkan keluaran yang benar. 
Perhitungan akurasi menggunakan Persamaan (8).

$$
\text { Akurasi }(\%)=\frac{\sum \text { data benar }}{\sum \text { data keseluruha }} \times 100 \%
$$

Sedangkan waktu komputasi adalah waktu yang dibutuhkan sistem dalam memproses data yang diberikan.

\subsection{Pengaruh Cell Size}

Pada percobaan pertama, akan dilihat pengaruh cell size terhadap akurasi dan waktu komputasi. Ukuran cell size yang diujikan yaitu $2 \times 2$ piksel, $6 \times 6$ piksel dan $8 \times 8$ piksel. Sedangkan parameter lainnya yaitu: block size $8 \times 8$ cell size, bin number 18 , dan hidden layer 50 dengan epoch 100. Dari tiga variasi cell size, didapatkan hasil performansi seperti yang terdapat pada Tabel 2.

Tabel 2. Pengaruh Cell Size pada Ekstraksi Ciri HOG

\begin{tabular}{|c|c|c|}
\hline Cell size & Akurasi (\%) & Waktu Komputasi (detik) \\
\hline $\mathbf{2} \times \mathbf{2}$ & $\mathbf{1 0 0}$ & $\mathbf{0 , 0 8 2 8}$ \\
\hline $6 \times 6$ & 95 & 0,0279 \\
\hline $8 \times 8$ & 85 & 0,027 \\
\hline
\end{tabular}

Berdasarkan Tabel 2, dapat dilihat bahwa akurasi tertinggi berada pada cell size $2 \times 2$ piksel sebesar $100 \%$ dengan waktu komputasi 0,0828 detik. Hal ini terjadi karena ukuran cell size $2 \times 2$ piksel dapat mengkodekan informasi bentuk citra mata untuk diidentifikasi secara visual dan membatasi jumlah vektor ciri pada HOG. Cell size yang melebihi $2 \times 2$ piksel tidak menghasilkan banyak informasi bentuk, sehingga waktu komputasi yang dihasilkan semakin cepat. Sedangkan ukuran cell size yang lebih kecil dari $2 \times 2$ dapat mengkodekan banyak informasi bentuk dan meningkatkan dimensi pada vektor ciri HOG, akibatnya waktu komputasi menjadi lebih lama. Oleh karena itu, dipilih cell size $2 \times 2$ piksel untuk dimasukkan pada parameter berikutnya.

\subsection{Pengaruh Block Size}

Pada percobaan kedua, akan dilihat pengaruh block size terhadap akurasi dan waktu komputasi. Ukuran block size yang diujikan yaitu: $2 \times 2$ cell, $8 \times 8$ cell dan $12 \times 12$ cell. Sedangkan parameter lainnya yaitu: cell size $2 \times 2$, bin numbers 18 , hidden layer 50 dengan epoch 100. Dari tiga variasi block size, didapatkan hasil performansi seperti yang terdapat pada Tabel 3.

Tabel 3. Percobaan Pengaruh Block Size pada Ekstraksi ciri HOG

\begin{tabular}{|c|c|c|}
\hline Block size & Akurasi (\%) & Waktu Komputasi (detik) \\
\hline $2 \times 2$ & 86,67 & 0,0887 \\
\hline $6 \times 6$ & 85 & 0,0888 \\
\hline $\mathbf{8} \times \mathbf{8}$ & $\mathbf{1 0 0}$ & $\mathbf{0 , 0 8 2 8}$ \\
\hline
\end{tabular}

Berdasarkan Tabel 3, dapat dilihat bahwa akurasi tertinggi berada pada block size $8 \times 8$ cell sebesar $100 \%$ dengan waktu komputasi 0,0828 detik. Hal ini terjadi karena semakin besar block size, maka sistem dapat menangkap perbedaan piksel dengan baik. Sedangkan semakin kecil ukuran block size maka sistem kurang mampu menangkap perbedaan piksel dengan baik.

\subsection{Pengaruh Bin Number}

Pada percobaan ketiga, akan dilihat pengaruh bin number terhadap akurasi dan waktu komputasi. Ukuran bin number yang diujikan yaitu: 9, 12 dan 18. Sedangkan parameter 
lainnya yaitu : hidden layer 50 dengan epoch 100 dan cell size $2 \times 2$ piksel, dan block size $8 \times 8$ cellyang memiliki performansi terbaik pada percobaan sebelumnya. Dari tiga variasi bin number, maka didapatkan hasil performansi seperti yang terdapat pada Tabel 4.

Tabel 4. Percobaan Pengaruh Bin Number pada Ekstraksi Ciri HOG

\begin{tabular}{|c|c|c|}
\hline Bin Number & Akurasi (\%) & Waktu Komputasi (detik) \\
\hline 9 & 98,33 & 0,0535 \\
\hline $\mathbf{1 2}$ & $\mathbf{1 0 0}$ & $\mathbf{0 , 0 6 2 9}$ \\
\hline $\mathbf{1 8}$ & $\mathbf{1 0 0}$ & $\mathbf{0 , 0 8 2 8}$ \\
\hline
\end{tabular}

Berdasarkan Tabel 4, dapat dilihat bahwa akurasi tertinggi berada di bin number 12 dan 18 sebesar $100 \%$ dengan rata-rata waktu komputasi 0,07 detik. Semakin besar bin number, maka waktu komputasi untuk menghitung histogram warna akan semakin lama.

\subsection{Pengaruh Hidden Layer pada ANN}

Pada percobaan keempat, akan dilihat pengaruh hidden layer terhadap akurasi dan waktu komputasi. Banyaknya hidden layer yang diujikan yaitu: 10, 50 dan 100 dengan epoch 100. Sedangkan parameter lainnya yaitu: cell size $2 \times 2$ piksel, block size $8 \times 8$ celldan bin number 12 dan 18 yang memiliki performansi terbaik pada percobaan sebelumnya. Dari tiga variasi hidden layer, maka didapatkan hasil performansi seperti yang terdapat pada Tabel 5.

Tabel 5. Percobaan Pengaruh Hidden Layer pada Klasifikasi ANN

\begin{tabular}{|c|c|c|c|}
\hline Bin number & Hidden layer & Akurasi (\%) & Waktu Komputasi (detik) \\
\hline \multirow{3}{*}{12} & 10 & 98,33 & 0,0632 \\
\cline { 2 - 4 } & 50 & 100 & 0,0629 \\
\cline { 2 - 4 } & 100 & 96,67 & 0,063 \\
\hline \multirow{3}{*}{$\mathbf{1 8}$} & 10 & 100 & 0,0823 \\
\cline { 2 - 4 } & $\mathbf{5 0}$ & $\mathbf{1 0 0}$ & 0,0828 \\
\cline { 2 - 4 } & 100 & 100 & 0,0812 \\
\hline
\end{tabular}

Pada Tabel 5, berdasarkan hasil pengujian dengan data latih menunjukkan nilai akurasi tertinggi berada pada bin number 18 untuk semua variasi hidden layer. Untuk hidden layer 50, pada saat bin number 12 dan 18, keduanya menghasilkan akurasi 100 . Variasi nilai hidden layer pada bin number yang sama, tidak berpengaruh signifikan terhadap waktu komputasi.

\subsection{Performansi Sistem dari Hasil Pengujian}

Setelah dilakukan empat pengujian parameter menggunakan data latih, diperoleh parameter terbaik cell size $2 \times 2$ piksel, block size $8 \times 8$ cell, bin numbers 18 , dan hidden layer 50 dengan epoch 100. Jumlah data uji sebanyak 60 citra, masing-masing terdiri dari 20 citra mata kolesterol normal, 20 citra mata berisiko kolesterol tinggi dan 20 citra mata kolesterol tinggi. Selanjutnya, dilakukan pengujian pengaruh hidden layermenggunakan data uji dan parameter terbaik cell size $2 \times 2$ piksel, block size $8 \times 8$ cell, bin numbers 18, dan epoch 100 .

Tabel 6. Hasil Pengujian Hidden layer pada Klasifikasi ANN

\begin{tabular}{|c|c|c|}
\hline Hidden layer & Akurasi (\%) & Waktu Komputasi (detik) \\
\hline 10 & 88,33 & 0,0856 \\
\hline $\mathbf{5 0}$ & $\mathbf{9 3 , 3 3}$ & 0,0862 \\
\hline 100 & 78,33 & 0,0942 \\
\hline
\end{tabular}


Pada Tabel 6, berdasarkan hasil pengujian dengan data uji menunjukkan akurasi terbaik, yaitu 93,33\% saat hidden layer 50 . Semakin besar nilai hidden, maka waktu komputasi menjadi sedikit lebih lama, namun tidak berpengaruh signifikan.

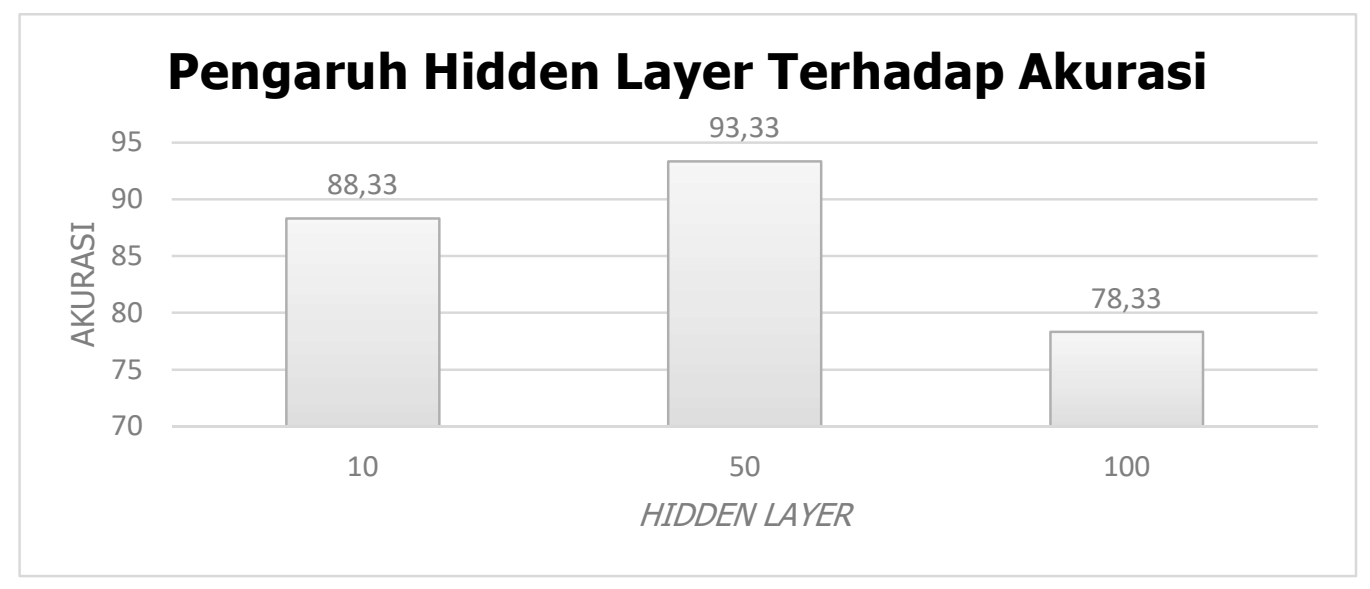

Gambar 7. Hasil Pengujian Hidden layer terhadap Akurasi

\section{KESIMPULAN}

Pada penelitian ini, telah dirancang suatu sistem untuk deteksi kolesterol melalui citra mata menggunakan metode HOG sebagai ekstraksi ciri dan ANN sebagai klasifikasi. Sistem dapat mendeteksi kadar kolesterol dengan tiga level klasifikasi, yaitu normal, berisiko kolesterol tinggi, dan kolesterol tinggi dengan akurasi sebesar 93,33\% dan waktu komputasi 0.00862 detik. Berdasarkan hasil percobaan dan penguijian pada sistem diperoleh kesimpulan sebagai berikut:

1. Metode HOG dapat mendeteksi level kolesterol dengan parameter cell size $2 \times 2$, block size $8 \times 8$, dan bin number 18 .

- Semakin besar cell size, maka tidak banyak menghasilkan informasi bentuk, sehingga waktu komputasi yang dihasilkan semakin cepat. Sedangkan ukuran cell size yang lebih kecil dapat mengkodekan banyak informasi bentuk, akibatnya waktu komputasi menjadi lebih lama.

- Semakin besar block size, maka sistem dapat menangkap perbedaan piksel dengan baik, akan tetapi waktu komputasi menjadi lebih lama.

- Semakin besar bin number, maka waktu komputasi untuk menghitung histogram warna akan semakin lama.

2. Metode ANN dapat mendeteksi level kolesterol dengan hidden layer sebanyak 50. Semakin banyak hidden layer akan terjadi over feeting. Sedangkan semakin sedikit hidden layer akan terjadi under feeting.

\section{UCAPAN TERIMA KASIH}

1. Terimakasih kepada Lembaga Penelitian dan Pengabdian Masyarakat (LPPM) Universitas Telkom, dan RISTEKDIKTI melalui skema Calon Perusahaan Pemula Berbasis Teknologi (CPPBT) 2018 atas pendanaan penelitian.

2. Terimakasih kepada TelkoMedika Bandung atas kerjasama dalam pengambilan data untuk penelitian. 


\section{DAFTAR RUJUKAN}

Adi, K. G., \& Rao, P. V. (2017). Analysis and Design of Cholesterol Detection in MRI Imaging. Journal of Ecophysiology and Occupational Health, 171\&2), 72 - 78.

Adi, K. G., Rao, P. V., \& Adi, V. K. (2015). Analysis and Detection of Cholesterol by Wavelets based and ANN Classification. Procedia Materials Science, 10, $409-418$.

Baghini, A. N., Soltanshahi, M., \& Rajabi, A. (2017). Diagnosis of Hyperlipidemia in Patients based on an Artificial Neural Network with PSO Algorithm. Journal of Advances in Computer Engineering and Technology, 3(1), 19 - 30.

Djalal, M. R., Hutoro, K. H., Imran, A. (2017). Kontrol Kecepatan Motor Induksi menggunakan Algoritma Backpropagation Neural Network, Elkomnika, 5(2), 138 - 148.

Gornale, S. S., Patravali, P. U., Marathe, K. S., Hiremath, P. S. (2017). Determination of Osteoarthritis using Histogram of Oriented Gradients and Multiclass SVM. International Journal of Image, Graphics and Signal Processing, 9(12), 41 - 49.

Kumar, S. V. M., Gunasundari, R., \& Ezhilvathani, N. (2016). Non-Invasive Measurement of Cholesterol Levels Using Eye Image Analysis Regression analysis. International Conference on Advances in Computational Intelligence and Communication (CIC 2016), (pp. 33 - 42).

Munir, R. (2004). Pengolahan Citra Digital. Bandung: Informatika.

Nazir, M., Jan, Z., \& Sajjad, M. (2017). Facial Expression Recognition using Histogram of Oriented Gradients based Transformed Features. Cluster Computing, 21(1), 539 - 548.

Novamizanti, L. (2009). Identifikasi Pola Iris Mata Menggunakan Dekomposisi Transformasi Wavelet dan Levenshtein Distance. Bandung: IT Telkom.

Ramlee, R. A., Ramli, A. R., Hanafi, Marsyita, Mashohor, M., Noh, Z. M. (2016). Comparison of Classifiers for Detecting the Corneal Arcus as a Symptom of Hyperlipidemia. Journal of Built Environment, Technology and Engineering, 1 (9), $154-159$.

Songire, S. G., \& Joshi, M. S. (2016). Automated Detection of Cholesterol Presence using Iris Recognition Algorithm. International Journal of Computer Applications, 133(6), 41 - 45. 